Canadian University Music Review

Canadian University Music Review

Revue de musique des universités canadiennes

\title{
Adam Krims, ed., with commentary by Henry Klumpenhouwer. Music/Ideology: Resisting the Aesthetic. Amsterdam: Gordon and Breach, 1998. 311 pp. ISBN 90-5701-321-5 (paperback)
}

\section{Murray Dineen}

Volume 20, numéro 2, 2000

URI : https://id.erudit.org/iderudit/1014460ar

DOI : https://doi.org/10.7202/1014460ar

Aller au sommaire du numéro

Éditeur(s)

Canadian University Music Society / Société de musique des universités canadiennes

ISSN

0710-0353 (imprimé)

2291-2436 (numérique)

Découvrir la revue

Citer ce compte rendu

Dineen, M. (2000). Compte rendu de [Adam Krims, ed., with commentary by Henry Klumpenhouwer. Music/Ideology: Resisting the Aesthetic. Amsterdam: Gordon and Breach, 1998. 311 pp. ISBN 90-5701-321-5 (paperback)]. Canadian University Music Review / Revue de musique des universités canadiennes, 20(2), 94-99. https://doi.org/10.7202/1014460ar

All Rights Reserved (C) Canadian University Music Society / Société de musique des universités canadiennes, 2000
Ce document est protégé par la loi sur le droit d'auteur. L’utilisation des services d'Érudit (y compris la reproduction) est assujettie à sa politique d'utilisation que vous pouvez consulter en ligne.

https://apropos.erudit.org/fr/usagers/politique-dutilisation/ 


\section{BOOK REVIEWS/COMPTES RENDUS}

Adam Krims, ed., with commentary by Henry Klumpenhouwer. Music/Ideology: Resisting the Aesthetic.Amsterdam: Gordon and Breach, 1998.311 pp. ISBN 90-5701-321-5 (paperback).

The eleven essays in this volume attest to the development of a new perspective within music theory. Of all the various domains of music scholarship, music theory has been the most reluctant to incorporate the innovations in disciplinary criticism that arose during the early 1970 s in literary studies. ${ }^{1}$ The present volume republishes several of the most important exceptions to that state of affairs: Suzanne Cusick, "Feminist Theory, Music Theory, and the Mind/Body Problem"; Alan Street, "Superior Myths, Dogmatic Allegories: The Resistance to Musical Unity"; Richard Littlefield and David Neumeyer, "Rewriting Schenker:Narrative-History-Ideology"; Marion Guck, "Analytical Fictions"; David Gramit, "Lieder, Listeners, and Ideology: Schubert's 'Alinde' and Op. 81"; Richard Littlefield, "The Silence of the Frames"; and Robert Fink, "Desire, Repression, and Brahms's First Symphony," and adds to them Jean-François Lyotard's "A Few Words to Sing," prescient remarks on Luciano Berio's Sequenza III: per voce femminile, first published some thirty years ago, which seem to anticipate so much criticism in the intervening years. Alongside this are three previously unpublished essays worth the price of the volume alone: editor Krims's introduction, "Postmodern Musical Poetics and the Problem of 'Close Reading"'; a concluding commentary by Klumpenhouwer, "Poststructuralism and Issues of Music Theory"; and Joke Dame's "Voices within the Voice: Genotext and Pheno-text in Berio's Sequenza III."

Space forbids anything but a cursory appraisal of individual essays. Krims's introduction sets the ground for the volume by means of two linked terms, musical poetics and close reading. By the former, Krims means the study of musical craft-long the rubric under which music theory has operated. ${ }^{2}$ By the latter, he means a particular kind of reading or textual exegesis, one that sacrifices breadth of vision for fineness of detail, not without dramatic loss, which has been the practice of music theory since the 1960s and the heady days of analysis-at-all-cost. That our knowledge of musical poetics might be, indeed is, sharply attenuated by the perspective, close or distant, with which we read is the heart of Krims's essay: "representation ... is not simply a what but also a how" (p.6).

${ }^{1}$ The present volume bears comparison with another, now some thirty years old, in which the post-structuralist project emerges: Richard Macksey and Eugenio Donato, The Structuralist Controversy: The Languages of Criticism and the Sciences of Man (Baltimore: Johns Hopkins University Press, 1972).

${ }^{2}$ See P. Murray Dineen, "Whither Our Undergraduate Core Curriculum in Theory?" Canadian University Music Review, no. 14 (1994): 146-59. 
Cusick considers the poetics of musical scholarship, theory only in the particular, in terms of the recently expanded notion of performance, borrowed in part from the work of Judith Butler on performance and gender. The nub of her essay is the perennial distinction between mind and body, given new light by bodily thinkers such as Butler. On the one hand stands a musical meaning aimed at and deciphered by the mind alone, a conception identical with if not implicit in masculine discourse:

The composer is masculine not because so many individuals who live in the category are biologically male, but because the composer has come to be understood to be mind-mind that creates patterns of sounds to which other minds assign meanings. The relationship of notes to each other [is] susceptible to apprehension as mind by mind (p. 45).

On the other hand stands a musical meaning that "must include theorizing about ... the practices of bodies (real ones) as well as the practices of the mind" (p. 46), to which the masculine is opposed.

Our incapacity to consider the latter precludes, for Cusick, any capacity to consider the feminine. To date our ability to consider the body has been antithetical to the hitherto largely masculine "mind" scholarship established in our journals and conferences. To remedy this state of affairs Cusick proposes an embodied reading that not merely accounts for the bodily experience but turns it to good advantage-an awareness of the conjoint physical and psychic intimacy implicit in the production of musical sound.

The central terms of reference in Alan Street's grand essay are surely allegory and ideology, the latter in the spirit of a citation taken from Paul De Man that describes the workings of ideology as "confusion of linguistic with natural reality, of reference with phenomenalism" (p. 70). Allegory is the tacit subtext of analysis, so tacit and yet so ubiquitous as to constitute the prime ideological motivation of much that passes as theory - to masquerade scholarly fictions about the way music works as fact. And allegory, especially as reworked by De Man and others like him-allegory as the "recognition of the artwork as an artificial construct in which meaning automatically depends on some form of continuous narrative or temporal unfolding" (p. 88) - undoes all the fictive certainty of ideological music theory by its very temporality.

If one can speak of a "within" and "without" to music theory in its modern guise and mean thereby, respectively, theorists who operate with Schenkerian and set-theoretic models, and theorists (Cusick for example) who do not, then we must place the collaborative pair David Neumeyer and Richard Littlefield in the former category. Their task is to loosen theoretical strictures from "within" by casting the narratives they tell-usually in a tacit manner-in historical and ideological terms. Their task is all the more difficult for this: to reconsider and rework Schenker, against the very organicist assumptions that gave rise to his work and most of the theoretical accretions to it since. And this explains, perhaps, why the essay feels somewhat out of its métier here, in a set of essays where to do readings of this still very close sort seems anachronistic. 
In this regard, Neumeyer and Littlefield's work, despite its apparent incongruity, is the one of the most important essays in the collection, for even a little loosening on the inside is worth a veritable barrage from without. The authors strive to force upon Schenkerian practice "a self-consciousness that it has woefully lacked to date" (p.129). Force is too strong a term; intimate might be more apt. To force self-consciousness upon the field would be too drastic; Schenkerian close reading, after all, is best done with only a necessary modicum of selfawareness. Too little, perhaps too late - this is a lonely essay. It whispers within where it should shout to be heard over the din from outside the Schenkerian stronghold.

Marion Guck's perspective is very much from the outside-an examination of the language used by three theorists, Edward Cone, Allen Forte, and Carl Schachter, in their respective analyses of high-Teutonic works by Schubert and Brahms. Her finding, not surprising in light of this collection, is that "fictional and structural accounts ... cannot be disentangled" (p.159). She does not go so far as to note that the precepts of structural analysis forbid this kind of mixturewith-fiction; instead she puts a kind face upon the matter:"I think that the practice of analysis would be improved if stories of involvement [authorial fictions] were less often subliminal, more often ... explicitly stated, because musical analysts are not simply communicating the musical facts by way of a neutral, transparent language" (p. 174). Twenty years ago this would have seemed a high heresy, and today it remains largely a sadly neglected truism.

The subject matter of David Gramit's investigation is not the ideology of theory but rather ideology as an object itself of theorizing. The sub-rosa text of the lied-intimate expression, personal communication, emotional insight-is seen as an ideology both in present-day service and in light of "the primary nineteenth-century audience for such music: the Austro-German educated classes" (p. 180). With the mention of class, Gramit turns his attention to a field of investigation dear to editor Krims and commentator Klumpenhouwer-ideology seen in light of class divisions and interests. This is surely a new, largely untrodden territory for the North American theorist - the musical object as the product and thus the reflection of social interest both past and present; fertile territory indeed.

Following a less socially conscious path, Richard Littlefield takes up the venerable contradiction of the narrative (to follow a plot entails both holding it at arm's length as fiction and yet immersing oneself in it as if it were the truth). He does so in the equally venerable guise of the artwork's frame, under the rubric "What goes on at the borders of a musical work?" (p. 213). In essence, the silence that surrounds the work is as necessary to its constitution as the sounds the work is said to comprise, and yet "[i]n 'normal' music analysis and interpretation, musical silence, like the picture frame [and the consciousness of narrative contrivance], tends to erase itself" (p. 227). Littlefield's point is that the self-erasing theoretical silence on the subject of the frames contrives an absolute musical object devoid of borders. By ignoring this contrivance, through extremely close readings, theory far too often treats the absolute musical object as a natural given. 
The Lyotard essay examines the relation of music and text, in a manner quite without replication, as the mutually subversive effect of the two upon each other and upon the whole. Lyotard illustrates his essay by reference to Luciano Berio's Sequenza III, which is also the object of the Dutch theorist Joke Dame's contribution. Dame begins with a far-too-familiar refrain: "Musicology in the Netherlands has always kept itself slightly apart from developments in the other humanities" (p. 233). Her remedy is to invoke French philosophy-primarily Julia Kristeva's concepts of "pheno-text" and "geno-text" adopted by Roland Barthes-as a means of illuminating Berio's text. Both Lyotard and Dame invoke bipolar worlds: on the one hand domains of musical understanding that might be called orthodox, superficial, and even straight; on the other hand, unorthodox, hidden, quasi-noumenal, and erotic or merely playful understandings. Dame does so in opposition to a description by István Anhalt, that of the work as a kind of psychosis-the pathology of a woman. Yes, there are deep and uncomfortable invocations in the work-along the lines of genotextual drives, subversions, repressions. But these are surely not the end-game, however, merely the antipode to a surface, a phenotext. And geno- and pheno-types engage in a delightful jouissance in Berio's work, in tribute to the famous clown Grock, whom Berio encountered at age eleven and who left him "overcome by contrary emotions" not knowing "whether to laugh or to cry" and thus doing both "simultaneously."

Robert Fink, in a delightful dance of prose and citation, takes up the er... burning torch lit particularly by Susan McClary (and which gave Pieter van den Toorn a notoriety beyond the confines of straight theory). Fink calls this sexual hermeneutics and aims to rehabilitate it:

In careless or naive hands, the sexual metaphor does have the potential to blur things, to-as van den Toorn rather melodramatically warns-" tyrannize music." But this is not because human sexuality is too crude and undifferentiated, or because sexuality has nothing to do with music; it is because the constructions of gendered sexuality we tend to apply to music are often just too simple, or are historically inappropriate. The solution is not to abandon the metaphor, but to refine it (p. 264).

To this refinement, Fink presses Freud, not only Freudian constructs but the very man himself, fraught with Brahmsian contradictions, repressions, and excess.

In the concluding commentary to the collection, Klumpenhouwer, it must be said, lays his cards clearly and deliberately on the table:

[I]t is my view that Marxist criticism offers the only possibility for sustained and successful critique of our current mode of production (described variously as "late," "postindustrial," or "postconsensual" capitalism) and all of its ideological forms and superstructural institutions, including contemporary music theory and analysis (pp. 290-91).

To conceive of music theory and analysis as a mode of production is both a breathtaking step and the logical outcome of this volume. Having had the procedures 
of making music theory illuminated in detail and in light of comparable domains of literature criticism, we are in a good position to adopt some rubric for a larger perspective on the practice itself. What better vehicle than an examination of theory as an intellectual production, after Bourdieu. Klumpenhouwer's recette is admirably succinct:

Marxist poetics ... will be carried out dually: first, by examining music as functioning in the category of ideology-that is to say, it needs to be investigated as an element of ideology proper, which along with institutions of religion, politics, and law constitute the superstructure of our social formation-and second, as a fulfilment of (basic) need required by all human beings, at least at the level of the collective (p. 308).

Klumpenhouwer goes on to refine this duality: ideology as

yet another locus where classes square off against each other ... how music-in its own terms-facilitates, mediates, and shapes both fundamental and special confrontations between social classes (p. 308);

and need as:

body and subjectivity. "Body" in this context, however, ought to mean "capitalized" bodies ... fragmented and alienated bodies of workers, regulated and conditioned through wage labor by time, to middle-class "bodies," organized by strictures of the "abstinence" question, which presents itself to the bourgeoisie as conflict between sustenance (under which one ought to understand fulfilment not only of basic needs but also of desires) and the further accumulation of capital (p. 308).

Now, for North American institutional music theory, as regulated (for example) by the Society for Music Theory, this is a whole new slate, something quite foreign (although our ethnomusicological cousins have been practising it for decades, had we cared to notice). And therein Klumpenhouwer locates a little project-as noted, the logical outcome of this volume-the Marxist investigation of music theories:

first, within a more general Marxist project of ideology critique, and second, from the perspective of music theory as "knowledge production," or, in other words, as an element of basic, or infrastructural, forces of production ( $\mathrm{p}$. 308).

These are the last paragraphs (along with a stark rejoinder to avoid the solipsism into which much Left-leaning writing falls) of a volume devoted to a critique of a theoretical domain that arose in the positivist days of the new university in the 1960s (Klumpenhouwer is too charitable by far in his appraisal of the origins of the SMT) and has retained a spectacular insularity ever since. A sense of ethics-responsibility to some higher criteria, quite apart from the field proper-has rippled across most other domains of textual criticism like a 
tsunami (much of it in the wake of the revelations about Paul De Man). Let us hope that with Klumpenhouwer's contribution we have the first tremors, and that these last paragraphs become the opening of a new work.

The potential readership for the volume stretches from the undergraduate theory seminar numbed by the recent spate of soporific surveys of the field, like Nicholas Cook's A Guide to Musical Analysis, to the accomplished scholar for whom the interdisciplinary vistas opened by these essays should prove refreshing. No doubt theory will continue to be taught as it has-the cultivation of extremely close reading skills-for many years to come, although, with burgeoning undergraduate populations and a decimation of the professorial ranks, just how long this can be sustained is a moot point. No doubt, accomplished scholars will also be able to ignore these developments so as to tread theoretical paths well worn since the putatively positivist 1960s, although, given the interdisciplinary breakdown of insular departmental mandates, just how long the university can continue to sustain scholars with such a fine focus is similarly moot. Indifference apart, to anyone with a modicum of adventure, the present volume should prove a tonic.

Murray Dineen

Kevin Bazzana. Glenn Gould: The Performer in the Work. Oxford: Clarendon Press, 1997. xxii, 297 pp. ISBN 0-19-816656-7 (hardcover).

Glenn Gould haunts us in many guises. Gould the pianist. Gould in thirty-two short films by François Girard. Gould-inspired ballets choreographed by James Kudelka. The Glenn Gould Studio inside the CBC headquarters in Toronto. Glenn Gould the professional performance school at the Royal Conservatory of Music. Gould the Foundation. Gould the bronze statue lolling on a bench outside the Glenn Gould Studio. Gould the conference. Glenn Gould the twiceyearly journal. Gould the maker of documentaries. Glenn the hit play by David Young. Gould the pill-popper. Gould the weirdo wearing wool gloves in summer. Gould the complete recordings on SONY Classical. Gould's Yamaha piano squatting like a massive black coffin in the lobby of Roy Thomson Hall, untouched, sacrosanct. Gould the icon. Gould the iconoclast.

Kevin Bazzana augments the trove of Gouldiana with an analysis of the pianist's performance objectives and practices. Bazzana begins by discussing Gould's projection of "idealism" in music, his belief in the performer as a cocreator of a composition, and performance as a critique of previous interpretations. When Gould revises compositions to emphasize structural clarity, he does so to enhance music that exists abstractly in the mind before it exists acoustically in the world. Bazzana applies such ideals to Gould's pianistic praxis: his profound sense of time; his rhythmic exactitude; his control of dynamics, especially in the pianissimo to mezzo-forte range; his détaché touch. This study is amply and expertly detailed and includes a CD sampler correlated to the text. Bazzana draws parallels between early and late recordings, and traces evolutions in Gould's thinking about performance over time.

Bazzana argues that Gould's approach to performance "raises basic issues 